\title{
Spatial patterns of wind and sea surface temperature in the Galician upwelling region
}

\author{
R. Torres ${ }^{1}$ and E. D. Barton \\ School of Ocean Sciences, University of Wales, Bangor, UK \\ P. Miller \\ Plymouth Marine Laboratory, Prospect Place, West Hoe, Plymouth, UK \\ E. Fanjul \\ Puertos del Estado, Madrid, Spain
}

Received 25 February 2002; revised 7 July 2002; accepted 25 July 2002; published 29 April 2003.

[1] Cape Finisterre is the most northwest point in the Galician region and separates the meridional west and zonal north coasts of Galicia. The wind field there has high spatial and temporal variability throughout the year. No clear seasonal signal is evident; upwelling and nonupwelling patterns alternate in all seasons. Two outstanding features of the Galician region are persistent upwelling near Cape Finisterre even when not present farther south and alternation of strong upwelling on north and west coasts. Up to now, explanations have relied upon particular dynamics of oceanic flow past Finisterre. We find that major features of upwelling around Finisterre are related to strong spatial structure in the wind field. Analysis of QuikScat wind data for July 1999 to May 2001 shows strong repeatable patterns in the synoptic wind field. These wind patterns emerge as the combination of the two dominant modes in a complex empirical orthogonal function (CEOF) analysis representing over $85 \%$ of the variance. Summer wind patterns give rise to characteristic distributions of upwelling along the coast and favor development of filaments in particular locations. The wind measured at Finisterre itself, often used as a general indicator of upwelling conditions around the Galician coast, is not always representative of the overall wind field. The relevant wind fields allowed a qualitative explanation of temperature structure seen in sea surface temperature images, and of differences in both the upwelling and downwelling regimes between the two

years. INDEX TERMS: 4227 Oceanography: General: Diurnal, seasonal, and annual cycles; 4279 Oceanography: General: Upwelling and convergences; 4516 Oceanography: Physical: Eastern boundary currents; 4504 Oceanography: Physical: Air/sea interactions (0312); KEYWORDS: SeaWinds, coastal upwelling, sea surface temperature, air-sea coupling, Iberia, wind patterns

Citation: Torres, R., E. D. Barton, P. Miller, and E. Fanjul, Spatial patterns of wind and sea surface temperature in the Galician upwelling region, J. Geophys. Res., 108(C4), 3130, doi:10.1029/2002JC001361, 2003.

\section{Introduction}

[2] In eastern boundary upwelling systems, coastal winds are the major forcing of residual circulation and largely determine the seasonality of the region. Wind forcing timescales of a few days to weeks are typically superimposed on a slowly varying seasonal signal, which influences the residual circulation and thereby the basin-scale response.

[3] The coast of Galicia (Iberian peninsula) constitutes the northern limit of the North Atlantic upwelling regime, which extends from 44 to about $10 \mathrm{~N}$. During the summer months, when the Azores high-pressure cell is in the central

\footnotetext{
${ }^{1}$ Now at Plymouth Marine Laboratory, Plymouth, UK.
}

North Atlantic and the Greenland low is weak, the associated trade wind blows southward along the coast of Iberia inducing upwelling and associated southward currents. In the winter months, when the Azores high is located farther south off NW Africa, and the Greenland low is deep and located off southeastern Greenland, the pressure gradient between the two systems results in an onshore and slightly northward wind off Iberia, and downwelling.

[4] The summer upwelling regime in the Galician coast is highly variable in time and spatially complex; the upper layer responds to rapid wind stress changes in 3 or fewer days [McClain et al., 1986; Huthnance et al., 2002]. Some of the complexity can be related to the irregular coastline, where Cape Finisterre marks the abrupt change between the meridional west and the zonal north coasts of Galicia. Capes or bays may induce important wind stress variations [Enriquez and Friehe, 1995], sometimes accelerating the flow to 
become supercritical [Winant et al., 1988]. Its kinetic energy is then trapped to produce localized upwelling maxima and upwelling filaments, for example, Pt. Conception, California [Barth and Brink, 1987].

[5] Finisterre is frequently the site of a stationary upwelling maximum [Blanton et al., 1984; Castro et al., 1994] and a recurrent upwelling filament [Haynes et al., 1993]. The latter found good agreement between the laboratory results of Narimousa and Maxworthy [1989] and spatial structure of filaments in the Portuguese and Spanish Atlantic coast and concluded that major capes in the region played an important role in filament formation. They suggested however that the filament near Finisterre was an "overshoot" of the coastal jet when upwelling occurs along the northern coast. McClain et al. [1986] noted that different wind directions resulted in upwelling either north or south of Finisterre but not usually both.

[6] The winter onshore wind regime is marked by the formation of a narrow, warm and salty surface poleward current along the Iberian Atlantic continental slope [Frouin et al., 1990; Haynes and Barton, 1990], which settles in November and disappears around May. Frouin et al. [1990] concluded that wind stress could account for only one fifth of the total poleward transport and considered thermohaline forcing to be the main driving mechanism. The latter is associated with the large-scale meridional pressure gradient in the upper $200-300 \mathrm{~m}$ caused by the poleward temperature decrease and the slope bathymetry [Huthnance, 1995]. The large-scale pressure gradient is a consistent feature and interannual variations of the poleward flow could be related to anomalous winds.

[7] Although the wind field plays a major role in the Galician region, it has largely been studied superficially in terms of upwelling indices estimated from geostrophic winds calculated for a cell centered offshore Finisterre. Large-scale studies by Bakun and Nelson [1991] and Wooster et al. [1976] have demonstrated the important seasonal variability of wind stress and wind stress curl, but were based on seasonally averaged winds at wide spacing. Only the temporal variability at a few coastal sites has been related with upwelling processes. For example, Fiúza et al. [1982] showed the seasonal and interannual dependence of coastal upwelling on coastal winds at Portuguese sites. In the present paper we analyze 2 years of wind data from the QuikScat mission, supplemented by in situ observations at nearshore buoys, in relation to AVHRR sea surface temperatures. First, seasonal differences and typical wind patterns are described. We then show how different coherent wind patterns lead to formation of the Finisterre filament and the differences in the upwelling north and south of the cape seen in sea surface temperature (SST) images. Spatial wind patterns related to the larger-scale pressure fields are used to explain variations between different upwelling years. We then describe the winter wind regime during both an "anomalous" and a "typical" year and finish by discussing the implications of the wind patterns in the evolution of the upwelling and nonupwelling regimes.

\section{Methods}

[8] The SeaWinds instrument on the QuikScat satellite is a specialized microwave radar that, since 21 July 1999, has measured near surface wind speed and direction twice daily in $1800 \mathrm{~km}$ swath bands. Wind speed measurements range from 3 to $20 \mathrm{~m} / \mathrm{s}$, with an accuracy of $2 \mathrm{~m} / \mathrm{s}$ and $20^{\circ}$ in direction. Spatial resolution of $25 \mathrm{~km}$ enables identification of fine-scale features poorly sampled with previous scatterometers. The small coast mask makes the data suitable for studying nearshore wind patterns and processes.

[9] Wind data were retrieved from the Jet Propulsion Laboratory web site (http://podaac.jpl.nasa.gov/quikscat/ qscat_data.html) as Level 3 Scientific product. The data set consists of global gridded values of meridional and zonal components of wind velocity on an approximately $0.25 \times$ 0.25 degree grid. The data were obtained from the Direction Interval Retrieval with Threshold Nudging (DIRTH) wind vector solutions contained in the QuikScat Level 2B data.

[10] The data from either the ascending pass (6AM LST equator crossing) or the descending pass (6PM LST equator crossing) were selected each day from 21 July 1999 to 16 May 2001, depending on which had the higher data density. The data cover the Coastal Transition Zone off Galicia, $40.5^{\circ} \mathrm{N}$ to $45.5^{\circ} \mathrm{N}$ and $6.5^{\circ} \mathrm{W}$ to $13^{\circ} \mathrm{W}$. Gaps in the data were dealt with by objectively interpolating the data. This method is equivalent to applying a spatial filter with smoothing scales $0.25^{\circ}\left(0.55^{\circ}\right)$ in longitude (latitude).

[11] The remotely sensed wind data were complemented with a set of in situ wind observations collected between 1 May and 15 August 1999 by 3 buoys from the Spanish agency Puertos del Estado Deep Water Network (DWN), moored near the Galician shelf break (Figure 1). They were located at $44^{\circ} 3.9^{\prime} \mathrm{N}, 7^{\circ} 31.1^{\prime} \mathrm{W}$ in $382 \mathrm{~m}$ north of Finisterre (Estaca de Bares); at $43^{\circ} 29.4^{\prime} \mathrm{N}, 9^{\circ} 12.6^{\prime} \mathrm{W}$ in $382 \mathrm{~m}$ off Cape Finisterre (Villano-Sisargas) and at $42^{\circ} 6^{\prime} \mathrm{N}, 9^{\circ} 23.2^{\prime} \mathrm{W}$ in 323 $\mathrm{m}$ (Silleiro). In the text we refer to them as N, F and S buoys, respectively. The DWN buoys also measured currents at $3 \mathrm{~m}$ depth with an UCM60 acoustic currentmeter. The data were measured hourly and filtered with a moving average filter A24A24A25 [Godin, 1991] with a cutoff frequency of 30 hours to remove tides and inertial components.

[12] SST from advanced very high resolution radiometer (AVHRR) for the same period and location were processed at Plymouth Marine Laboratory using the Panorama software [Miller et al., 1997].

[13] Wind data were further processed by calculating complex empirical orthogonal functions (CEOFs) similar to Münchow [2000]. CEOFs provide an objective means to summarize the wind measurements and to establish the dominant mesoscale features coherent within the data set.

[14] The wind data are expressed in a two dimensional complex vector where the $u$ component is the real part and $v$ the imaginary part (equation (1)) and $X_{i}(i=1 \ldots N)$ denote the location and $t_{k}(k=1 \ldots M)$ time.

$$
W\left(X_{i}, t_{k}\right)=u\left(X_{i}, t_{k}\right)+\hat{\imath} v\left(X_{i}, t_{k}\right)
$$

In matrix form it is,

$$
W=\left(\begin{array}{ccc}
W_{1}(1) & \ldots & W_{1}(N) \\
\vdots & \ddots & \vdots \\
W_{M}(1) & \ldots & W_{M}(N)
\end{array}\right)
$$




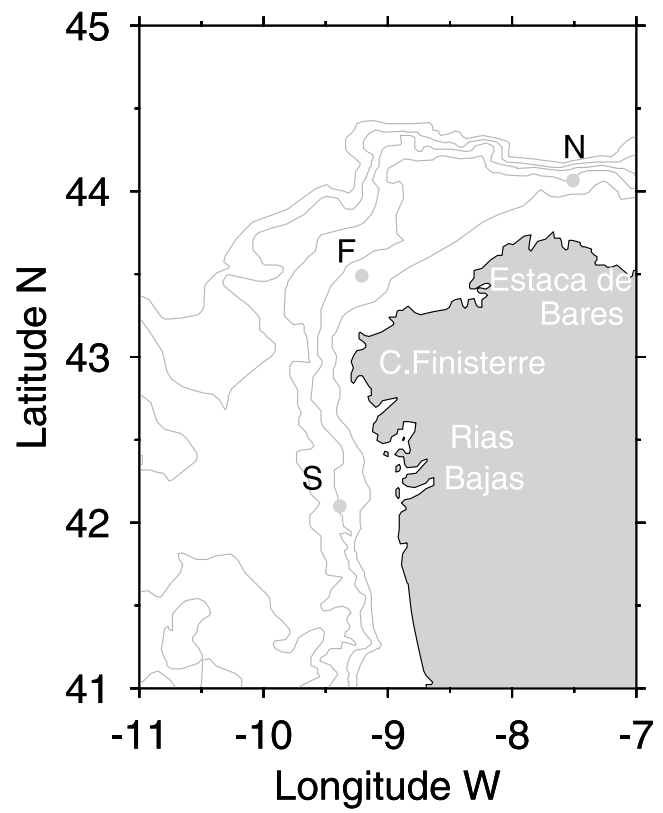

Figure 1. Map of the region of study with the position of the main coastline features and instruments.

For each data series the temporal mean was subtracted and the modified covariance matrix $R$ calculated,

$$
R=W \times W^{*} /(M-1),
$$

where the $*$ denotes the complex conjugate and results in a $M \times M$ matrix. We have normally dealt with matrices containing more locations than points in time $(\mathrm{N}>$ $\mathrm{M})$, which results in a smaller matrix than the true covariance matrix. The CEOFs are obtained by solving,

$$
R \times D=D \times \Lambda,
$$

where $\Lambda$ are the real eigenvalues of the covariance matrix, which are identical irrespective of which way the covariance is calculated [Kelly, 1988]. $D$ are the complex eigenvectors which are different from the results we would have obtained using an $N \times N$ covariance matrix but they can be calculated from,

$$
E=W^{*} \times D,
$$

by which we obtained $E$, an $N \times M$ matrix. Therefore we calculate a smaller number of eigenvectors than the $N$ eigenvectors that are defined for the problem but, because only the first few are significant, the lost ones are irrelevant.

[15] The time varying amplitudes are obtained as shown in equation (5),

$$
A=W \times E,
$$

where $A$ is complex, having magnitude and orientation, and represents the amplification factors for the spatial patterns. The original data can be reconstructed from,

$$
F=A \times E^{*} .
$$

[16] The orientation of the temporal amplitudes and spatial patterns are relative to an arbitrary reference [Kundu and Allen, 1976]. To facilitate their interpretation the spatial patterns and temporal amplitudes are rotated along the direction of the semimajor principal axis of the corresponding amplitude time series [Merrifield and Winant, 1989]. Furthermore, the amplitude and spatial modes are normalized in such a way that amplitude series have uniform variance, and the spatial modes have units of $\mathrm{m} / \mathrm{s}$ and correspond to a vertical amplitude of value 1 .

[17] Two important properties of EOFs are that the spatial distributions are orthogonal and that their time series are uncorrelated over the data set. Thus the EOFs are uncorrelated modes of variability. Usually a large portion of the variance can be explained by a small number of modes. To decide which modes are significant the sampling error associated with the EOF analysis was estimated following the method described by North et al. [1982],

$$
\delta \lambda_{i}=\lambda_{i}\left(\frac{2}{n}\right)^{1 / 2}
$$

where $\delta \lambda_{i}$ refers to the sampling error of the ith mode, $\lambda_{i}$ is the ith eigenvalue, and $n$, the number of independent measurements or degrees of freedom, is calculated after Davies [1976], according to

$$
n=\frac{N \Delta t}{\tau} .
$$

Here, $\Delta t$ is the sampling interval, $N$ is the number of records, and $\tau$ a decorrelation timescale,

$$
\tau=\sum_{i=-\infty}^{\infty} C_{u u}(i \Delta t) C_{v v}(i \Delta t) \Delta t
$$

$C_{u u}(t)$ and $C_{v v}(t)$ are the lagged autocorrelation functions of $U(t)$ and $V(t)$ series. The sampling errors associated with each eigenvalue of the first 6 eigenfunctions are computed using equations (7)-(9). Only those eigenmodes whose errors do not overlap are distinct.

\section{Seasonal Evolution of the Galician Region}

[18] The seasonal wind regime can be broadly divided into summer upwelling and winter downwelling regimes. The median of the wind field for summers 1999 (JulyOctober) and 2000 (May-October) in Figures 2a and 2c, shows upwelling favorable winds along the Atlantic coast of Galicia strengthening to the south. North of Cape Finisterre the winds are locally downwelling favorable. The typical winter downwelling regime is characterized by onshore winds on the Atlantic coast as in 2000-2001 (November-April, Figure 2d). This picture is however complicated by interannual variations in the location of the pressure systems (Figure 2b), such as in winter 1999-2000 (November-April). The Azores high remained in a more northern location than winter 2000-2001 and the median of the winds shows a circulation like the summers of 1999 and 2000 (Figures 2a and 1c), albeit weaker.

[19] Partly in response to the annual winds the coastal regime typically changes from upwelling in summer to 

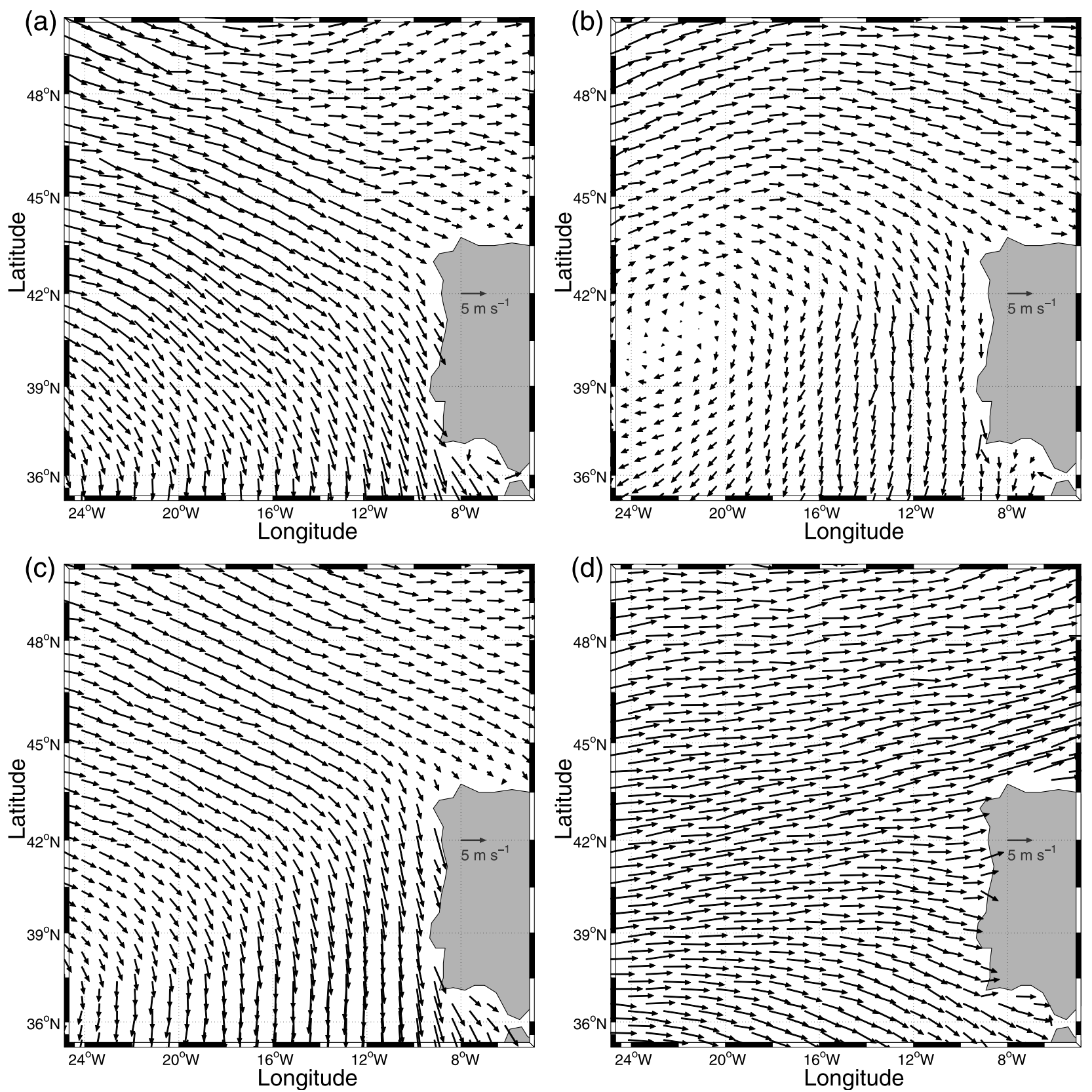

Figure 2. Median wind fields from (a) summer 1999 (July-October), (b) winter 1999 (NovemberApril), (c) summer 2000 (May-October), and (d) winter 2000 (November-April).

downwelling and poleward flow along the slope in winter, as in the period of study (Figure 3). During both summers upwelling took place from June-October. The first sign of upwelling in 1999 appeared in early June as a cold thin strip next to the Atlantic coast off Galicia. By mid-June (Figure $3 a)$, the upwelling was stronger in the north coast and the Finisterre filament was starting to develop. The filament persisted through June and July but weakened in August (Figure 3b). No other filament developed during this season, as is often the case here. Years 1995 and 1996 (not shown) also saw a predominance of north coast upwelling and the Finisterre filament over other filaments. Examination of weekly composites of SST imagery for the period 19932000 suggests that the Finisterre filament is normally the first one to appear and is accompanied by north coast upwelling.
[20] Poleward flow, suggested in SST by a warm tongue extending along the shelf break (Figure 3c), developed from 20 October and persisted till early May. Several periods of weakened (end November) or absent (March) warm anomaly suggest suppression of the poleward flow.

[21] Upwelling in 2000 started earlier, the first signs appearing in mid-May north of Cape Finisterre. At the same time the Finisterre filament started to develop (Figure 3d) although it disappeared at the end of May, and never reached the size of the previous year. Upwelling occurred intermittently until mid-July (Figure 3e), then almost continuously for the rest of the season but no clear filament developed at the Cape. Moreover, north of Finisterre upwelling was very weak while to the south, upwelling extended beyond the $200 \mathrm{~m}$ isobath with intermittent filament formation. The 


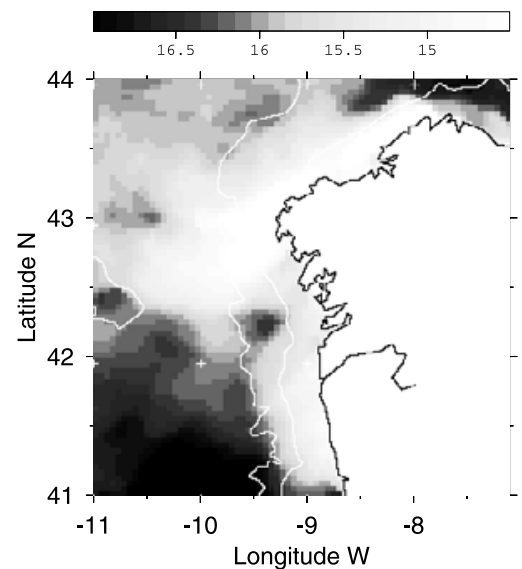

(a) June 20-26 1999

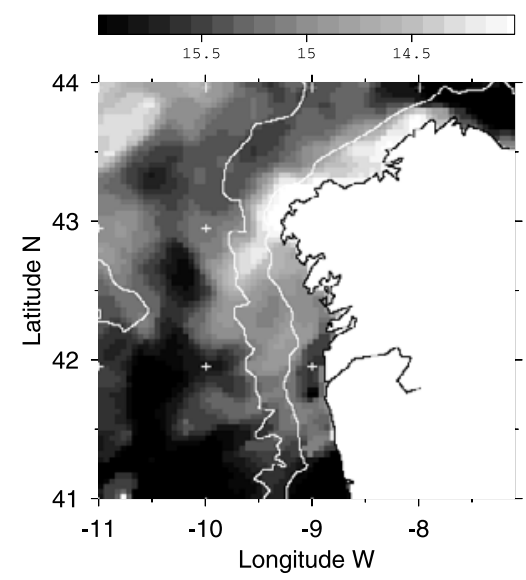

(d) May 21-27 2000

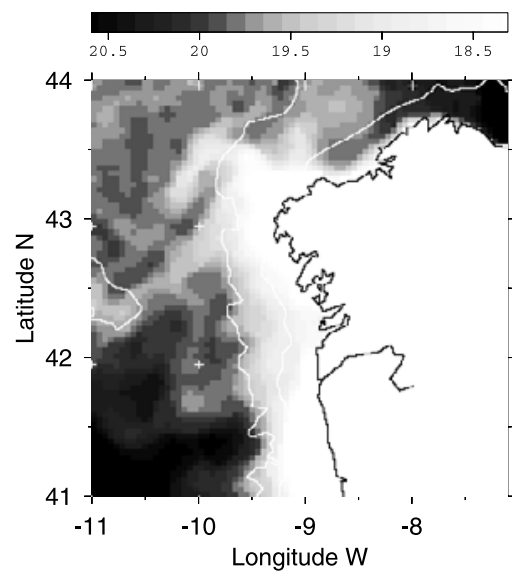

(b) Aug 15-21 1999

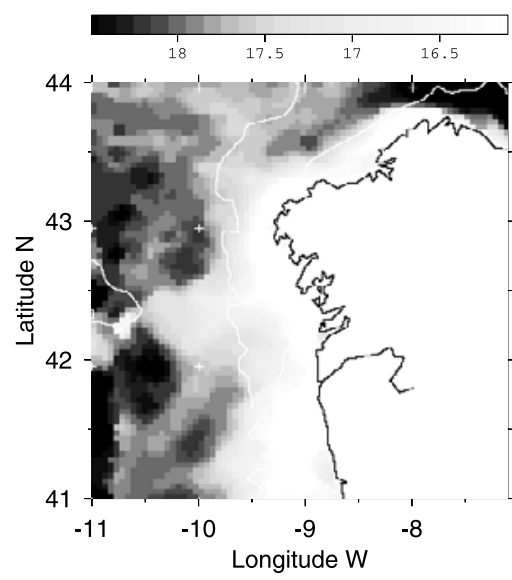

(e) July 16-22 2000

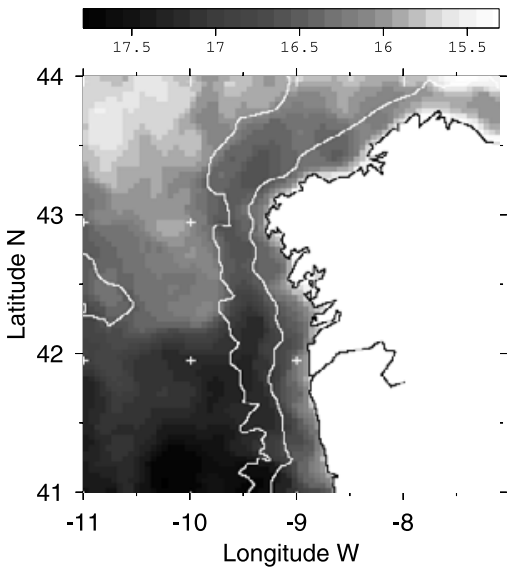

(c) Nov 7-13 1999

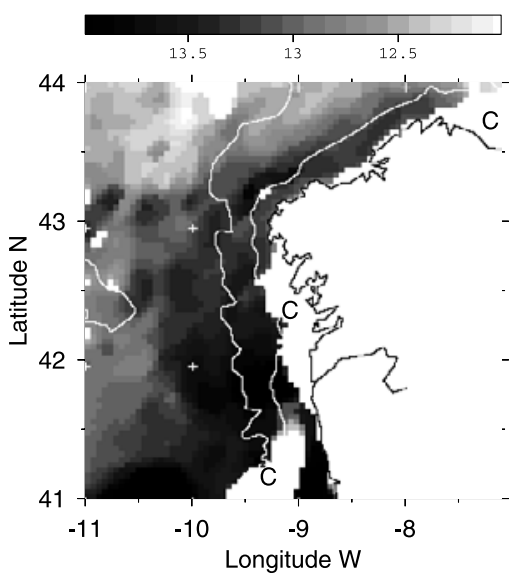

(f) Mar 11-17 2001

Figure 3. Samples of weekly SST average images for the period of study. Note the different temperature scales. White patches labeled $\mathrm{C}$ represent clouds.

insignificant filament activity was compensated by an upwelling season extending to mid-November.

[22] Poleward flow in the following season was first seen in early December 2000 and lasted till late April. Its SST signal in March (Figure 3f) shows a narrow extension of warmer water turning east around cape Finisterre along the northern coast.

\section{Common Spatial Wind Patterns}

[23] A CEOF analysis was performed on the 2 year record comprising both upwelling and nonupwelling regimes. Further CEOF analysis of shorter data periods to investigate regime or interannual differences showed a high consistency in the spatial modes and variance distribution with the full record analysis. Figures 4 and 5 show the overall representative results. The mean wind field (Figure 4a), subtracted from the data prior to the EOF calculations, resembles the median (Figures $2 \mathrm{a}$ and $2 \mathrm{~b}$ ). The first two modes account for $88 \%$ of the total variance (Figure $4 \mathrm{~b}$ ) and are statistically distinct since the uncertainty of the eigenvalues do not overlap with any of the other eigenvalues [North et al., 1982]. The decorrelation timescale for all QuikScat data was shorter than 2 days and a conservative value of 3 days was used in all uncertainty estimates.
[24] Figure 5 depicts the spatial pattern of the largest 2 modes. The first mode (Figure 5a), a spatially coherent wind field, represented $74 \%$ of the total variance. The second mode (14\% of total variance), where the wind field is opposed in direction north and south of Finisterre, adds wind curl to the first mode (Figure 5b). The mode shows a minimum of wind speed and maximum wind curl along a line running southwest from Finisterre with a uniform intensification to the north and strengthening nearshore to the south. This mode would contribute to Ekman pumping along the line of minimum wind intensity.

\subsection{The 1999-2000 Season}

[25] The instantaneous orientation depends on the direction of the complex amplitudes. The patterns shown in Figure 5 correspond to a unit amplitude vector in the principal axis direction, represented in Figure 6 by a unit vector pointing vertically upward. A unit vector to the right represents the same pattern rotated 90 clockwise. For clarity, the direction of northward winds is represented by the arrow to the right of Figure 6. The amplitude time series for mode 1 (Figure 6) is highly variable for the period 13 October 1999 to 28 October 2000 comprising one upwelling/nonupwelling cycle as identified from SST imagery. The largescale wind is far from unidirectional and changes occur very 

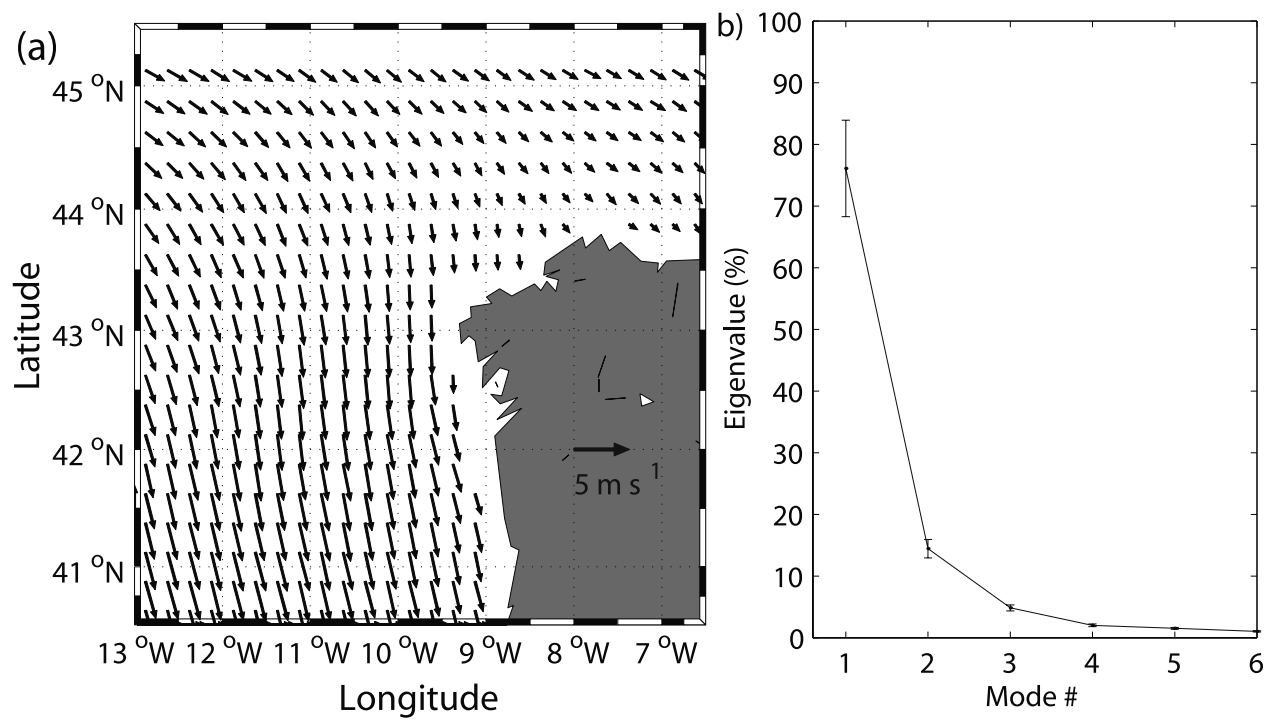

Figure 4. Mean and variance distribution from the overall CEOF analysis.

rapidly, as the short decorrelation time suggests. For this year, the expected seasonal signal was absent although both upwelling and downwelling events were stronger in winter than in summer, in particular from October to January. The downwelling events, lasting for about 4-5 days, alternated with longer and more directionally consistent upwelling events. Nonetheless, downwelling was predominant during October, December, and April.

[26] Directional differences in the wind occur between summer and winter. In winter, mode 1 shows two main orientations; the first corresponds to that in Figure 5a, rotated 10-40 clockwise. Adding the mean field makes the wind south of Finisterre more aligned with the coast. The second preferred orientation corresponds to the less common downwelling winds, i.e., rotated $160^{\circ}-190^{\circ}$ to those of Figure 5a. In summer the preferred orientations are that shown in Figure 5a (i.e., no rotation) and $150^{\circ}-190^{\circ}$.
[27] In winter, mode 2 shows similar orientations to mode $1\left(0^{\circ}-30^{\circ}\right.$ and $\left.\sim 180^{\circ}\right)$. During summer, orientations between $130^{\circ}-170^{\circ}$ were dominant during summer with a small contribution from $10^{\circ}-30^{\circ}$.

[28] Combining the mean field with the first two modes for the preferred orientations (Figure 7) produces wind fields that typify the entire 2 year record. Figure $7 \mathrm{a}$ represents a combination of unit amplitude vectors directed at $30^{\circ}$ for mode 1 and 2 (but is representative of a wider range of orientations \pm 10 ). This wind field, dominant during March (shaded window in Figure 6), shows intensified southwestward winds parallel to the coast of Finisterre, slightly onshore on the north coast and weaker and slightly offshore south of the Cape. This pattern favors upwelling along the north coast between Cape Finisterre and Estaca de Bares, and especially off Finisterre and will be referred to here as predominant upwelling on north coast (PUNC). (a)

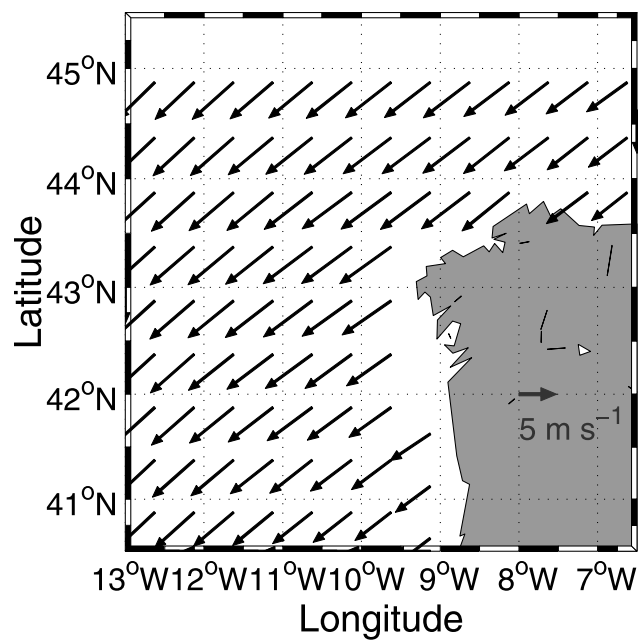

(b)

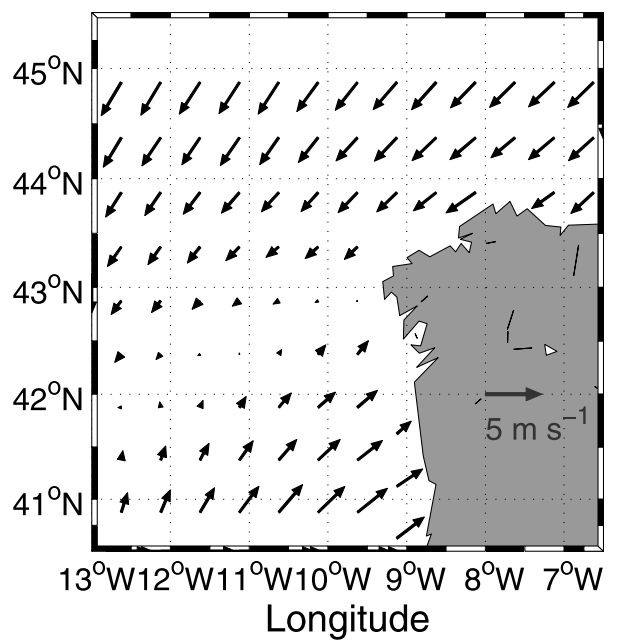

Figure 5. EOF wind distinctive modes from the overall CEOF analysis: (a) first and (b) second. 


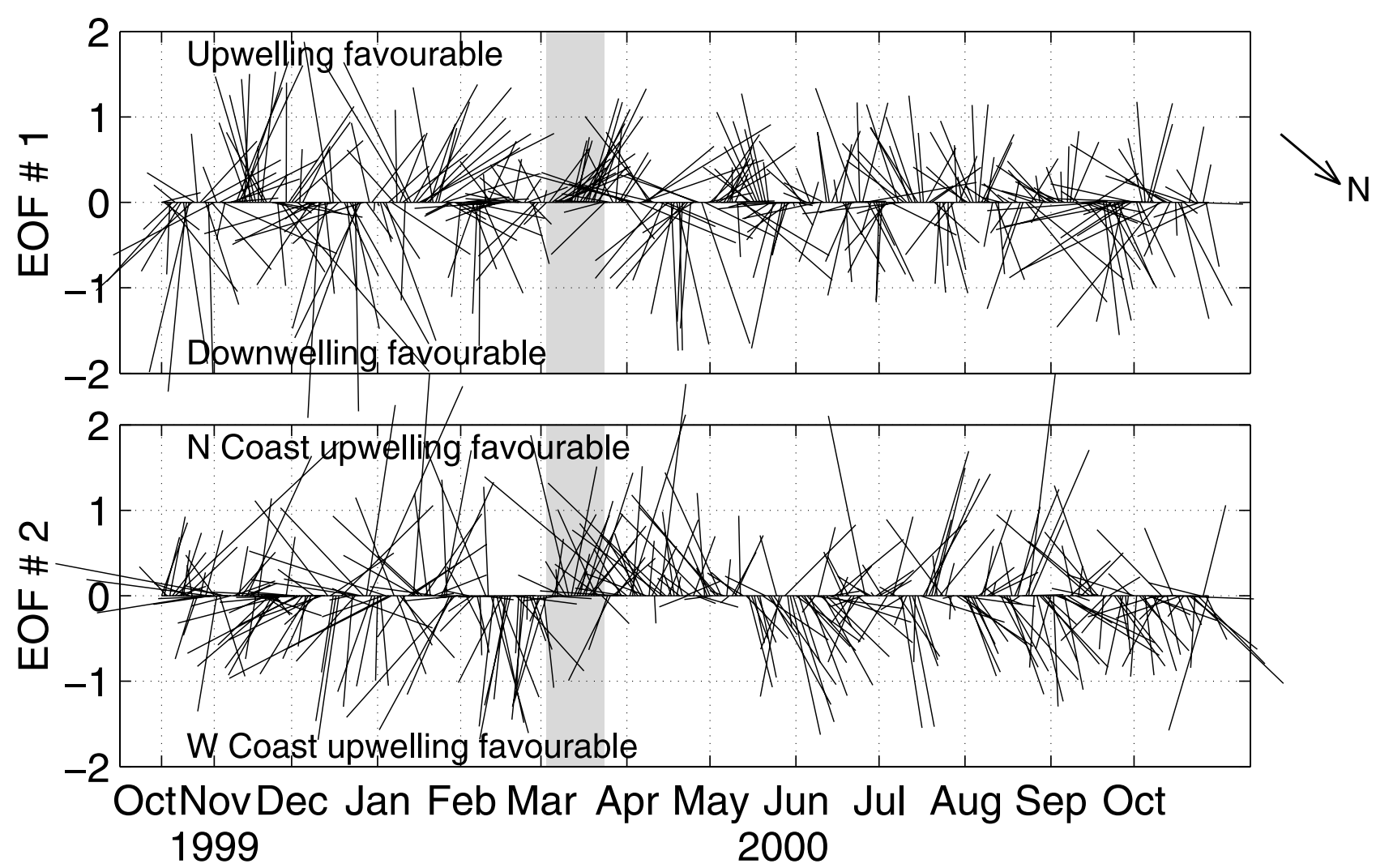

Figure 6. Amplitude time series for the seasonal analysis (13 October 1999 to 28 October 2000). The shaded intervals are referred to in the text. The arrow on the right points at the geographical north for the largely coherent wind field of mode 1.

[29] Figure 7b is a combination of unit amplitude vectors directed toward 180 for both modes and shows typical downwelling winds. This situation with northeastward winds stronger north of Finisterre, is found in December and February. Varying the orientation of mode 2 produces different downwelling intensifications north and south of Finisterre. They will generically be referred to as DOWN (downwelling off west and north coasts).

[30] Figures $7 \mathrm{c}$ and $7 \mathrm{~d}$ correspond to orientations $0^{\circ}$ $\left(300^{\circ}\right)$ and $150^{\circ}\left(300^{\circ}\right)$ for mode 1 (mode 2 ) respectively and typify the dominant upwelling patterns for summer 2000. Both wind fields are more intense along the west coast and favor upwelling along the west coast (predominant upwelling on west coast (PUWC).

\subsection{Winter of 2000-2001}

[31] Unlike the winter wind regime of 1999-2000, which largely resembled the summers 1999 and 2000, the winter of 2000-2001 was more "typical". The median for November to April (Figure 2d) showed a spatially coherent wind field of $5 \mathrm{~ms}^{-1}$ with an E-SE direction near coast south of $43^{\circ} \mathrm{N}$ rotating to a E-NE orientation farther north. The CEOF analysis (20 October 2000 to 10 May 2001) yielded two modes $(80 \%$ and $10 \%$ of the total variance respectively) similar to those in the overall analysis (Figure 5), though more mutually perpendicular.

[32] The amplitude series (Figure 8) show that sustained, if variable, DOWN wind fields were dominant, particularly from late November until early April. From 12 to 28
February a PUNC upwelling wind field, like March 2000 (Figure 7a) occurred. Mode 2 showed few strong events. Upwelling winds had two preferred orientations: 310-340 and $0-40$, similar to Figures $7 \mathrm{~d}$ and $7 \mathrm{c}$. Downwelling winds were predominantly westerlies or southwesterlies. Downwelling patterns persisted for $<6$ days, while upwelling wind periods of $<14$ days occurred in February and April to May.

[33] The narrow, warm tongue indicative of poleward flow first appeared over the slope in SST images in early December after a week of downwelling favorable winds. The poleward current persisted until the second half of February, when the tongue disappeared from the north coast following 5 days of PUNC winds up to $12 \mathrm{~ms}^{-1}$. It was not reestablished until 11 March (Figure 3f), 10 days after the return to DOWN winds. Winds changed to PUWC on the 6 April and remained predominantly so until the end of the record on 10 May. The upwelling response in this season appears slow. Although first signs of weakening poleward flow occurred during 8-14 April, when the SST differences between the warm tongue and oceanic waters reduced, west coast upwelling did not appear until 29 April to 5 May after 14 days of continuous upwelling winds.

\section{PUNC Wind Pattern Effects on Upwelling}

[34] Spatial variability of coastal upwelling can be explained largely by the dominant wind patterns of Figure 7. Winds on the 21 July 1999 (Figure 9a) were PUWC upwelling favorable similar to Figure $7 \mathrm{c}$. Wind speeds up to 
(a)

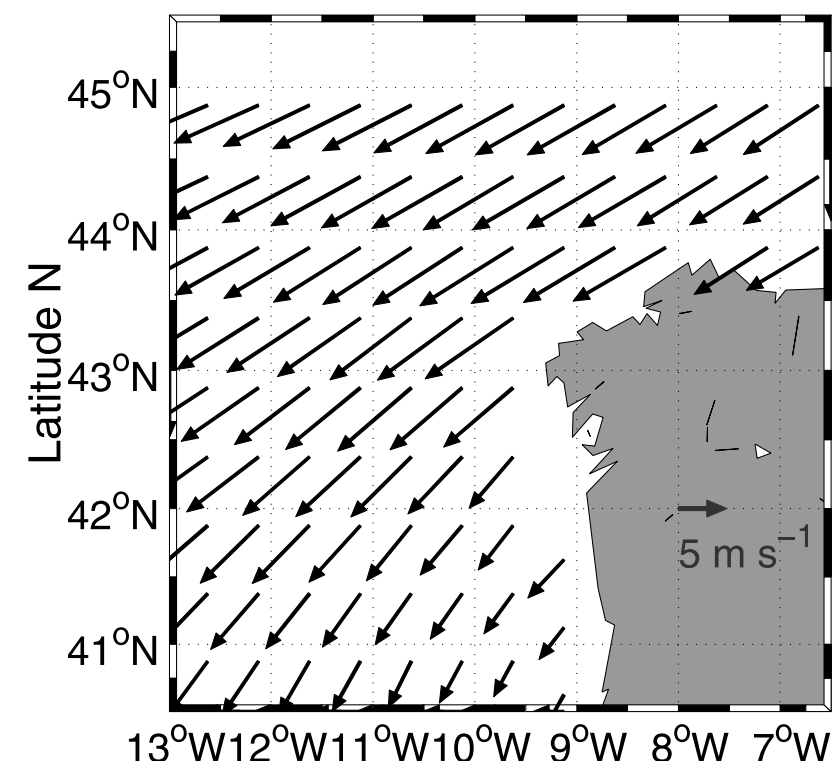

(c)

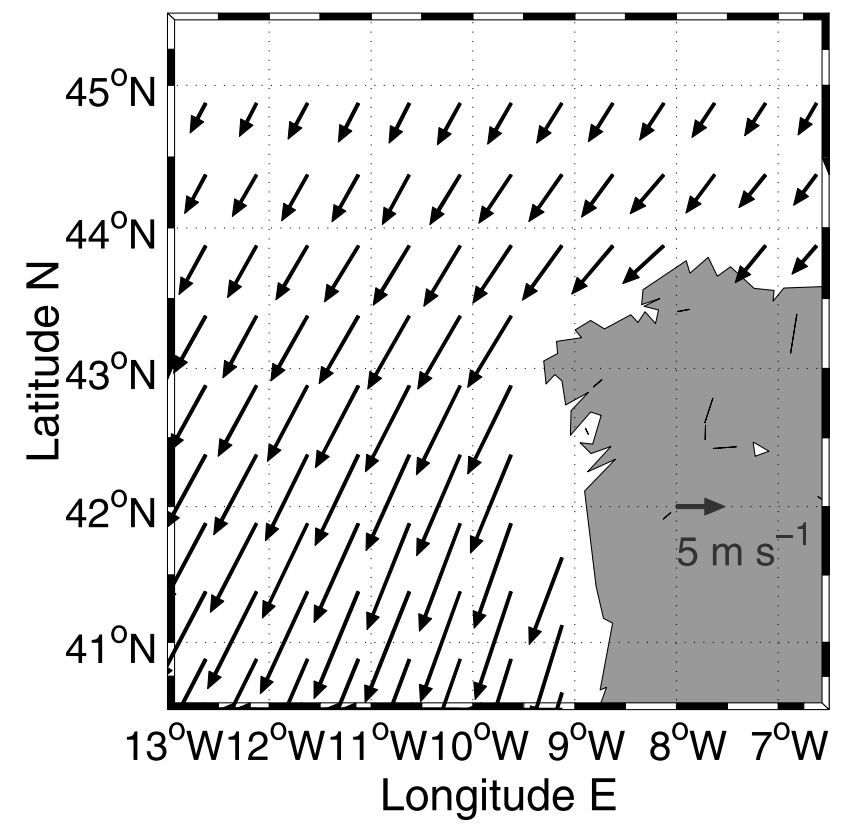

(b)

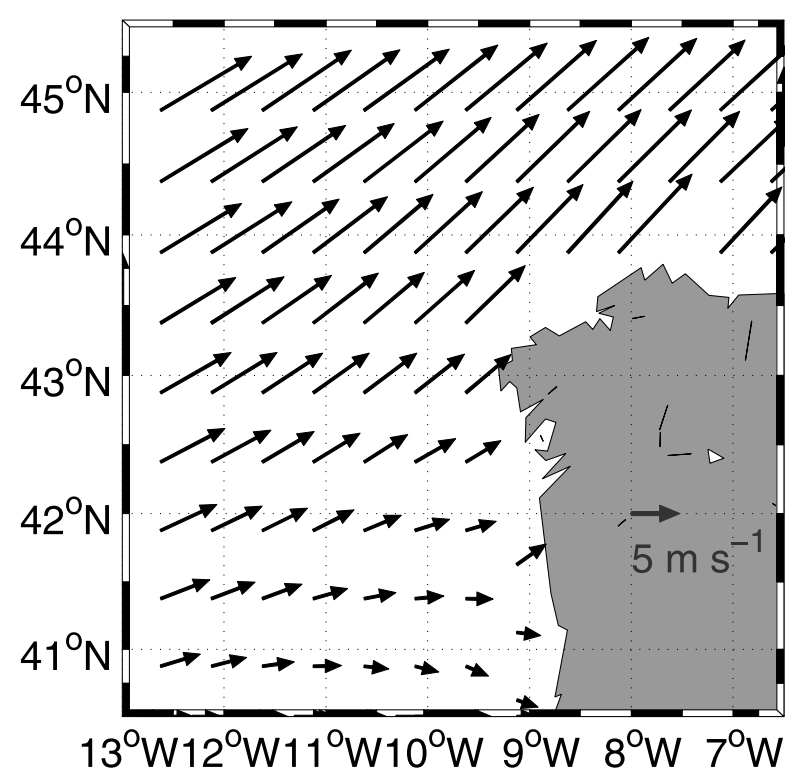

(d)

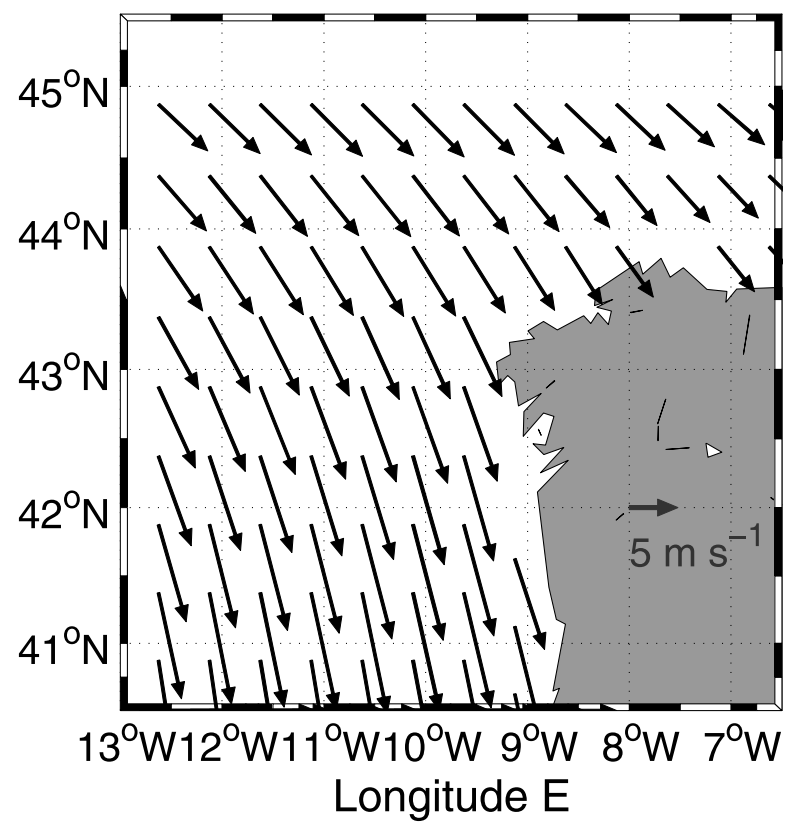

Figure 7. Typical reconstructed wind patterns found in 1999-2000 showing combination of unit vectors for modes 1 and 2 directed (a) $30^{\circ}$ and $30^{\circ}$, (b) $180^{\circ}$ and $180^{\circ}$, (c) $0^{\circ}$ and $150^{\circ}$, and (d) $300^{\circ}$ and $150^{\circ}$.

$10 \mathrm{~m} / \mathrm{s}$ parallel to shore forced strong upwelling off Finisterre and the west coast. The SST image for the 21 July (Figure 9b) shows minimum temperatures around Finisterre and a clearly identifiable Finisterre filament. West coast upwelling extended south to $41^{\circ} \mathrm{N}$ and offshore to the $1000 \mathrm{~m}$ isobath. Weak north coast upwelling persisted despite onshore winds north of the Cape. However, the wind rotated clockwise through a PUNC pattern to that of 23 July (Figure 9c), dominated by mode 2 as in Figure $5 \mathrm{~b}$. This enhanced upwelling in the north coast, strengthened the Finisterre filament, but was downwelling favorable on the west coast. Although this particular pattern with northward winds south of Finisterre is infrequent, strong development of the Finisterre filament to the exclusion of those farther south in, for example, 1995 and 1996, suggests similar wind fields can predominate over part of the upwelling season.

[35] The DWN buoy wind observations give further support to the Finisterre filament-PUNC link. Hourly buoy 


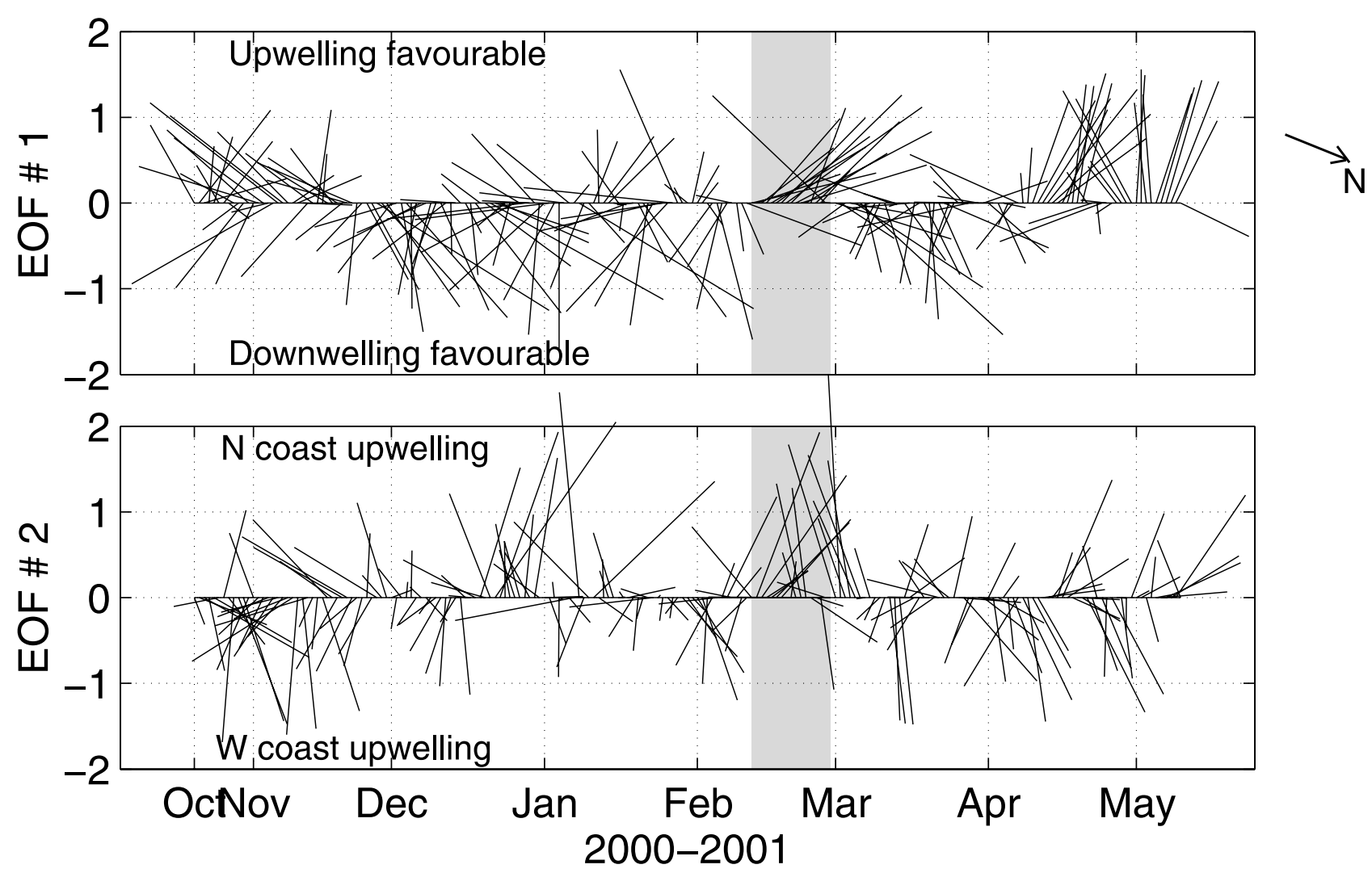

Figure 8. Amplitude time series for the winter 2001 analysis (20 October 2000 to 10 May 2001). The shaded intervals are referred to in the text. The arrow on the right points at the geographical north for the largely coherent wind field of mode 1.

and scatterometer data for the period of overlap agreed well, with correlations $r^{2}=0.96,0.97$ (significant at 99\% level of confidence) for the $\mathrm{U}$ and $\mathrm{V}$ components respectively. Upwelling favorable winds were consistent from 7 to 23 June when signs of upwelling appeared in SST images. The period contained two pulses of northerly winds that gradually strengthened and rotated to northeasterly and easterly favoring north coast upwelling. The SST images for the same period show the development of strong upwelling in the north coast, weaker upwelling along the west coast, and the rapid growth of the filament at Cape Finisterre. At the same time, buoy current data showed peak offshore velocities at $\mathrm{F}$ of $22 \mathrm{cms}^{-1}$, more than twice those at $\mathrm{S}$.

[36] The Finisterre filament followed similar development in 1995 and 1999. Coastal upwelling first appeared in SST imagery at the end of May along both coasts but a week later upwelling was mainly north of Finisterre. By 11 June 1995 a filament extended $125 \mathrm{~km}$ from the cape and upwelling on the west coast had disappeared (Figure 10a). This situation persisted through July but by August north coast upwelling had weakened. Lowest temperatures were located on the west coast, where upwelling extended to the $1000 \mathrm{~m}$ isobath. After 6 August frontal instabilities started to develop (Figure 10b) at $43.25^{\circ} \mathrm{N}$ (off Finisterre) and at $42.25^{\circ} \mathrm{N}$ and $41.25^{\circ} \mathrm{N}$, well known locations for filaments [Haynes et al., 1993]. They continued to grow until 27 August when upwelling was reestablished north of Finisterre. The Finisterre filament continued to grow as the west coast upwelling weakened. After 17 September, the situa- tion of August was repeated, i.e., the Finisterre filament retreated, upwelling weakened north of the Cape while it intensified farther south, and the instabilities developed again. This evolution can be explained by alternation of the typical PUNC and PUWC wind patterns of Figures $7 \mathrm{a}$ and $7 \mathrm{~d}$, favoring upwelling on one or other of the coasts.

[37] Though no in situ wind observations are available for 1995 this interpretation is supported by Sea Level Pressure (SLP) data from the National Centers for Environmental Prediction (NCEP) reanalysis project at the Climatic Diagnostics Center web site [http://www.cdc. noaa.gov/cdc/reanalysis/]. The SLP field in June 1995 (Figure 11a) indicates winds parallel to the north Iberian coast and offshore on the west coast, as in the PUNC pattern of Figure $7 \mathrm{a}$, with tight packing of the isobars indicating strong winds at Finisterre. During July 1995 the SLP field (Figure $11 \mathrm{~b}$ ) shows the Azores high well to the south $\left(33^{\circ} \mathrm{N}\right.$, $40^{\circ} \mathrm{W}$ ), producing a PUWC wind pattern similar to Figure $7 \mathrm{c}$ that favored west coast upwelling and weakening of the Finisterre filament, as was observed (Figure 10b).

\section{PUWC Wind Pattern Effects on Upwelling}

[38] In some years, the Finisterre filament does not develop and west coast upwelling with (e.g., 1998) or without (e.g., 2000) filament development dominates. The CEOF mode 1 amplitude time series for summers 1999 (19 July to 30 September) and 2000 (1 May to 31 October) accounted for $76 \%$ and $72 \%$ of the variance respectively. 


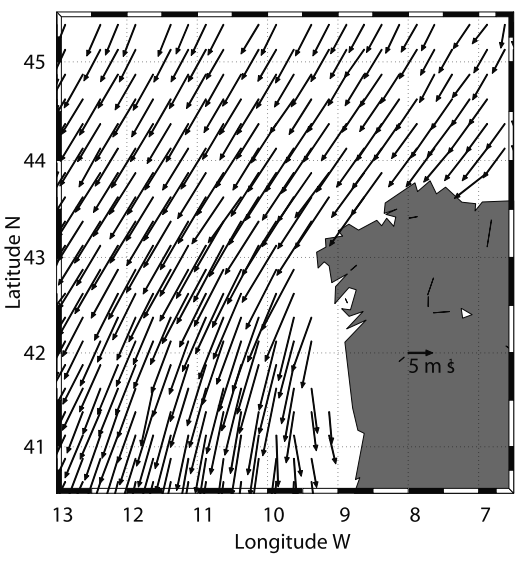

(a) Wind field 21 July

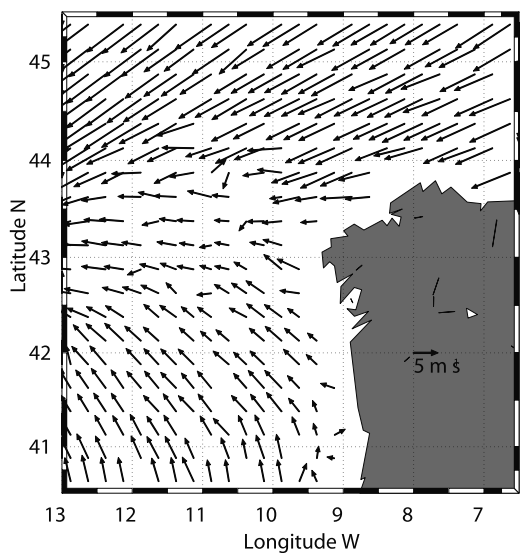

(c) Wind field 23 July

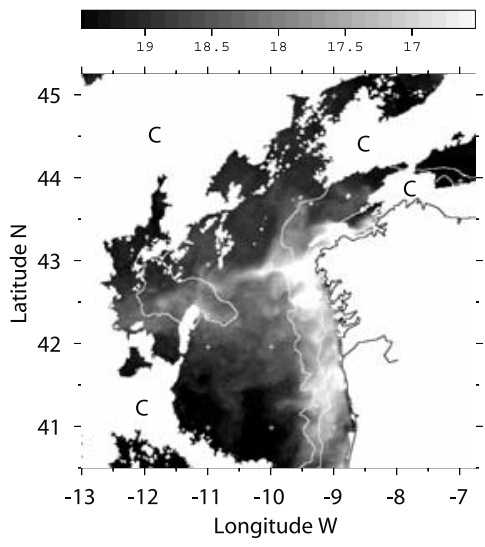

(b) SST 21 July

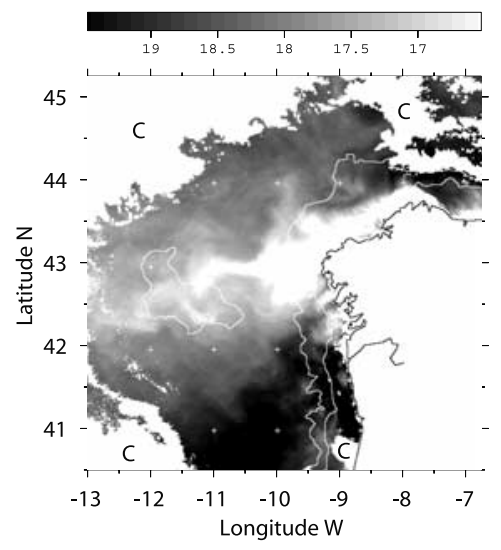

(d) SST 23 July

Figure 9. Wind fields and SST images from 21 and 23 July 1999. White patches labeled C represent clouds.

The mean fields were similar in both summers (Figures 2a and 2c) to the typical PUWC pattern (Figure 7d) and in both the first two modes (not shown) were like the overall modes (Figure 5a and 5b). However, during summer 1999 few wind events lasted long enough to produce significant west coast upwelling (shaded in Figure 12a) and filaments. During summer 2000, repeated short west coast upwelling events of various intensities again alternated with shorter downwelling periods. Even the two most persistent upwelling events (6-19 July and 31 July to 10 August) generated only short $80 \mathrm{~km}$ filaments at $42.25^{\circ} \mathrm{N}$ and $41.25^{\circ} \mathrm{N}$ (Figure 3e) that weakened after each event.

[39] In contrast, west coast upwelling and full filament formation dominated during summer 1998, when sustained upwelling favorable winds occurred from June [Smyth et al., 2001]. During June-August a series of filaments formed, grew and merged near $41.25^{\circ} \mathrm{N}, 42^{\circ} \mathrm{N}$ and $43^{\circ} \mathrm{N}$. During August both Finisterre and west coast upwelling coexisted although the former did not develop a filament and west coast upwelling persisted until September [Barton et al., 2001].

\section{Discussion}

[40] The period under study, July 1999 through to May 2001, showed no clear seasonal wind signal, with upwelling and downwelling winds distributed year-around. Similar results were obtained by Nogueira [1998], who found that only $20 \%$ of the variability in daily Ekman transport off Cape Finisterre over 9 years was associated with the seasonal cycle, while $70 \%$ was concentrated at frequencies $<30$ days. Nogueira et al. [1997] showed from harmonic analysis that the average upwelling event length was $T=15$ \pm 5 days, close to our estimate of $14 \pm 2$ days. Comparing our data with those of Kosro et al. [1991] off California, we observe that although cycles of upwelling winds/relaxation take place in both regions, Galicia is more variable in wind speed, direction and persistence. Much of the summer variability relates to anticyclones moving northeastward over the bay of Biscay.

[41] Differing patterns of upwelling favorable wind fields force different responses in the system favoring either north or west coast upwelling (PUNC and PUWC, respectively). Summer 1999 experienced winds favorable to north coast upwelling and Cape Finisterre filament development while summer 2000 was more typified by west coast upwelling. Both years experienced highly variable winds that did not persist long enough for upwelling filaments to develop on the west coast. The strongest development of west coast filaments in recent years occurred in 1998, when west coast upwelling favorable winds lasted from June to early August 


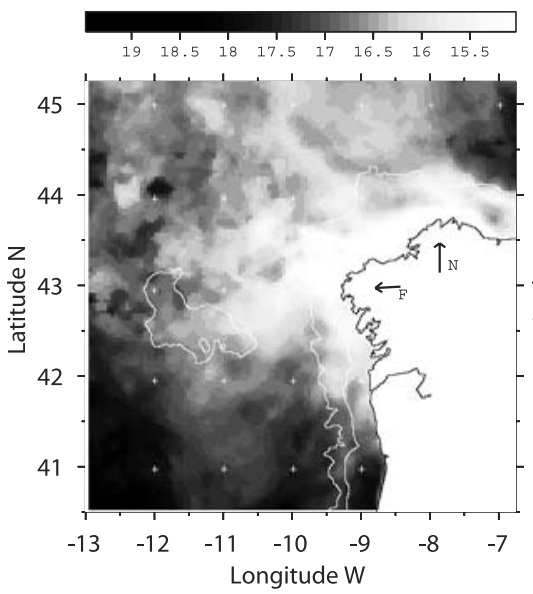

(a) June 18-24

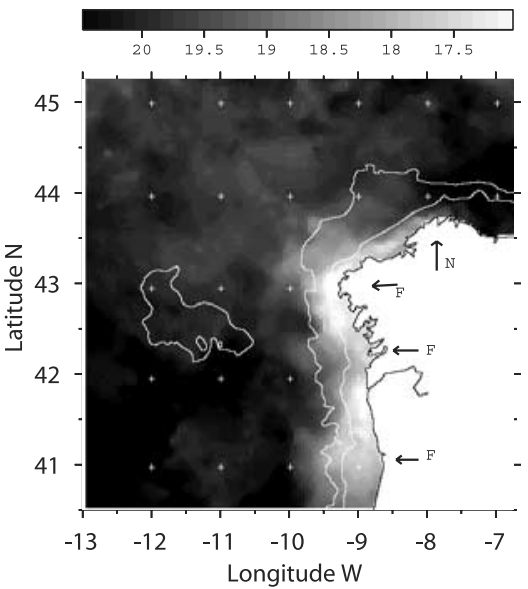

(b) August 06-12

Figure 10. SST weekly averaged images from 1995. Arrows labeled F mark known locations for filaments. Arrows labeled N mark the north coast site with largest upwelling differences.

with few interruptions. These sustained upwelling favorable winds maintained a sharp upwelling front that allowed the development and growth of the west coast instabilities into upwelling filaments.

[42] Much has been hypothesized about the generation of upwelling filaments. Roed and Shi [1999] and Haynes et al. [1993] reported a clear link between bottom topography and filament formation in the Galician region on the basis of models and observations, respectively. However, our results show that the Cape Finisterre filament is clearly dependent on particular wind conditions for its development. The mere presence of upwelling at Finisterre is not sufficient. Although small-scale instabilities sometimes develop off the Cape (see Figures 9b, 9d, and 10a), it requires a well developed north coast upwelling for them to grow into a full sized filament. At these times the wind field is like that of Figure $7 \mathrm{a}$ and the filament extends offshore along the line of maximum wind curl identified in mode 2 in Figure 5.

[43] The wind curl produces open ocean upwelling velocities given by $w=k \cdot\left(\nabla \times \frac{\tau}{f \rho}\right)$, where $k, \tau, f$ and $\rho$ are vertical unit vector, wind stress, Coriolis parameter and density of water. An example for winds measured on 22 July 1999 shows positive upwelling Ekman pumping velocities along the line of maximum wind curl extending toward the west coast (Figure 13). Maximum vertical velocities were $6 \mathrm{md}^{-1}$ near Cape Finisterre decreasing to $1 \mathrm{md}^{-1}$ farthest offshore. Calculations on a similar day in March 2000 yielded the same pattern but vertical velocities were (a)

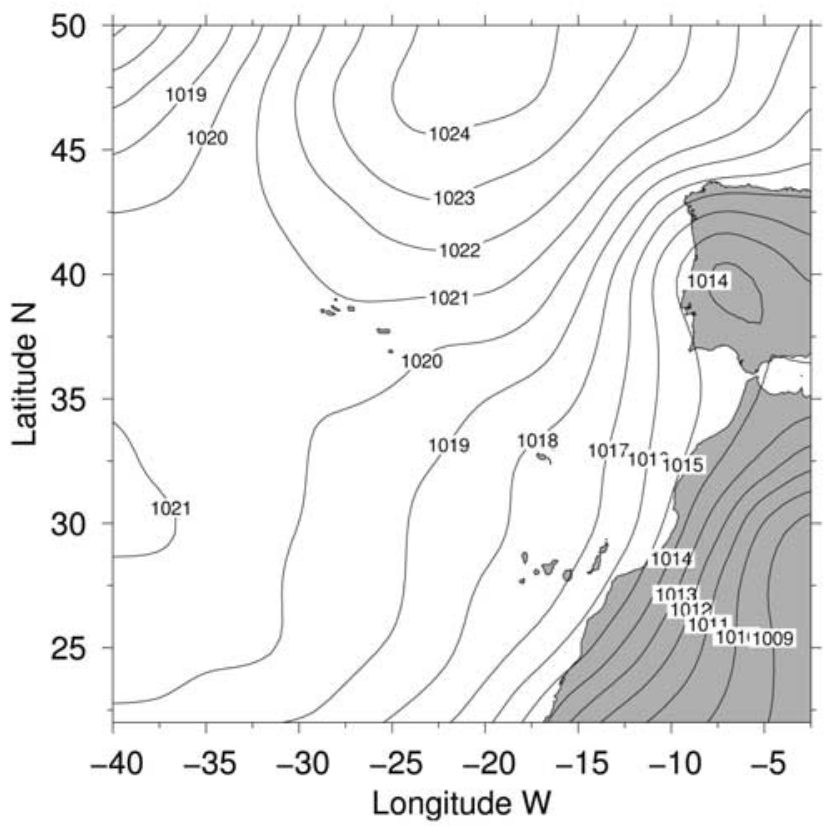

(b)

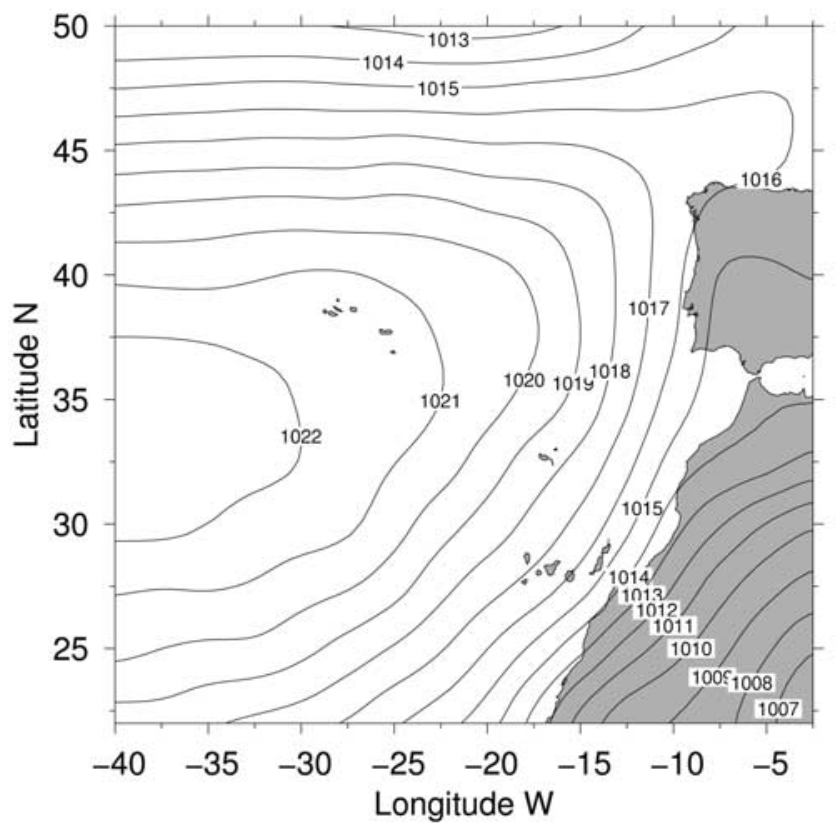

Figure 11. Monthly averages of sea level pressure for (a) June and (b) July 1995. 

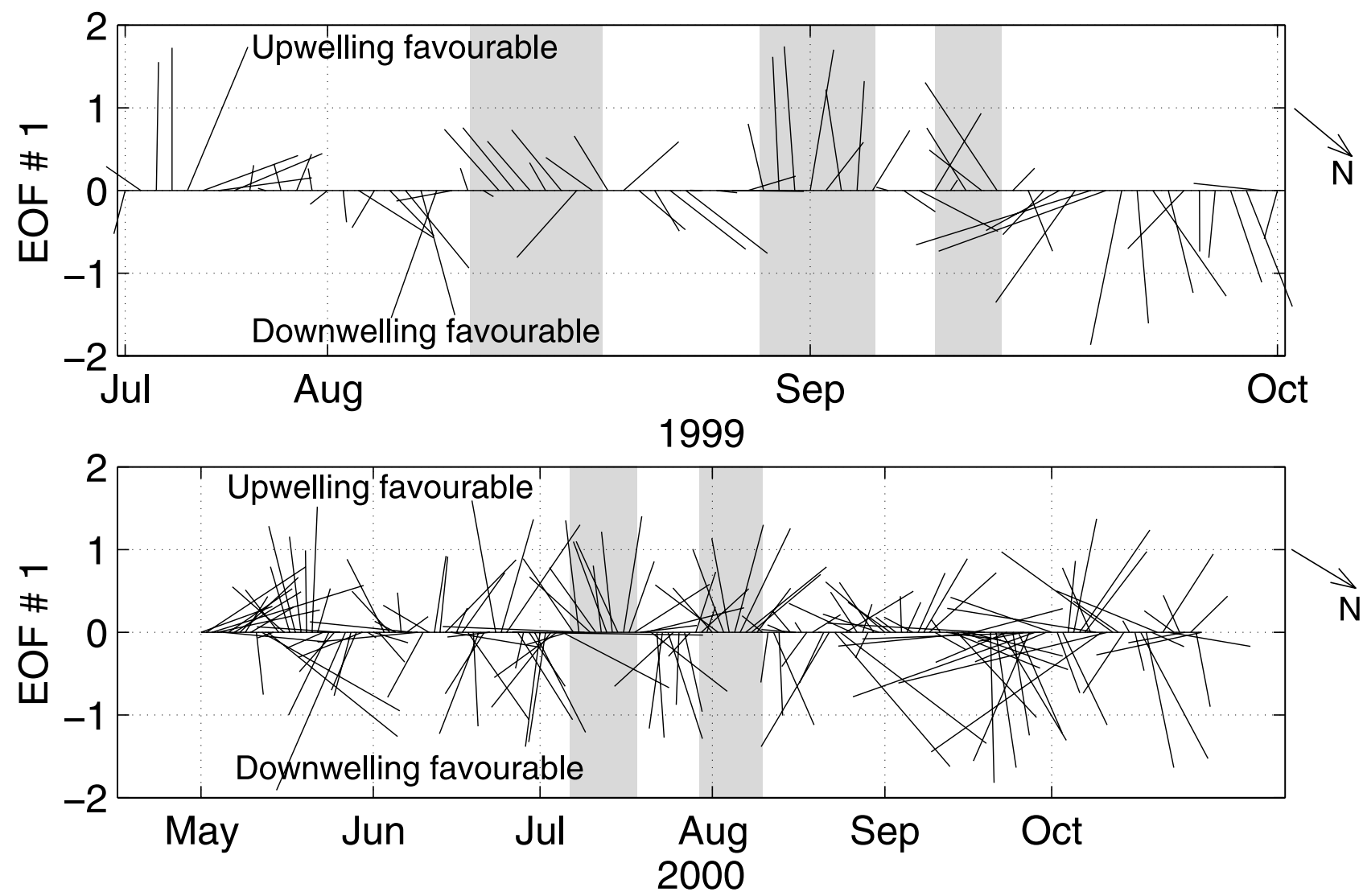

Figure 12. Amplitude time series for the summers 1999 (19 July to 30 September) and 2000 (1 May to 31 October). The shaded intervals are referred to in the text. The arrow on the right points at the geographical north for the largely coherent wind field of mode 1 .

smaller by a factor of 2. The strong winds in June 1995 (Figures 11a and 11b) were again like the 1999 case. We conclude summer occurrences of this wind pattern lead to upwelling velocities of 5-6 $\mathrm{md}^{-1}$ off Cape Finisterre decreasing offshore. These are smaller than the ones (up to $20 \mathrm{md}^{-1}$ ) reported by Münchow [2000] off Point Conception, California. His finer sampling covered a much smaller area which defined a maxima wind curl ridge $80 \mathrm{~km}$ long and $10 \mathrm{~km}$ wide. In our case, the ridge extends $320 \mathrm{~km}$ in length and $90 \mathrm{~km}$ in width and vertical velocities are likely to reach higher values nearer to the shore at Cape Finisterre.

[44] Münchow [2000] reported flow separation in the wind field at Point Conception in the presence of upwelling. He argued that the lower sea surface temperatures enhanced the vertical stability of the marine layer, which is capped by a temperature inversion. As by Enriquez and Friehe [1995], the marine layer flow becomes supercritical and separates from the coast causing the wind curl and Ekman pumping velocities. We see some evidence of wind flow separation in the lee of Cape Finisterre during the summer upwelling regime. For example the buoy wind data for 7 July 1999 (Figure 14) show measured north coast and Finisterre winds flowing nearly opposite to west coast winds, suggestive of strong flow separation at the cape. Similar north coast winds were common throughout March 2000 and after 14 June 1999, but flow separation only occurred in the presence of cold upwelled water around Cape Finisterre during the 1999 examples. However, finer-scale wind observations near Finisterre and atmospheric observations would be needed to reach a definitive conclusion.

[45] The existence of recurring wind curl west of Cape Finisterre will influence the vertical water structure to cause doming of the isopycnals. Capes also have a significant impact on the alongshore variability of the upwelling flow field [Crepon et al., 1984; Dale and Barth, 2001; Rosenfeld

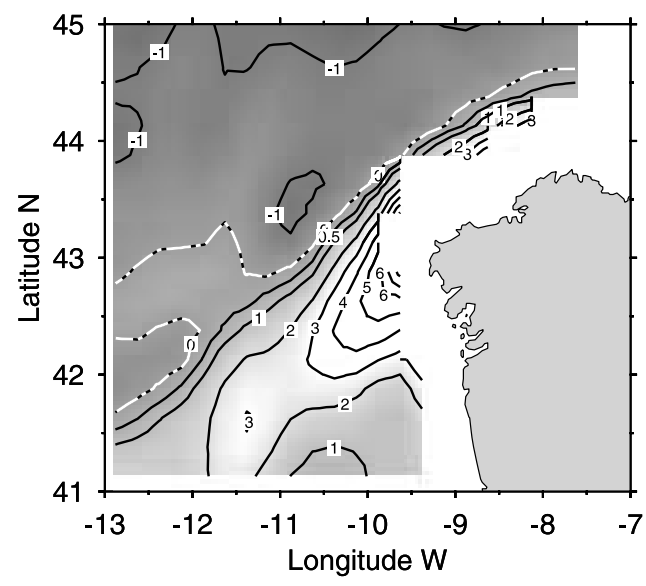

Figure 13. Vertical Ekman pumping velocities on 22 July 1999 in $\mathrm{md}^{-1}$, positive upward. 


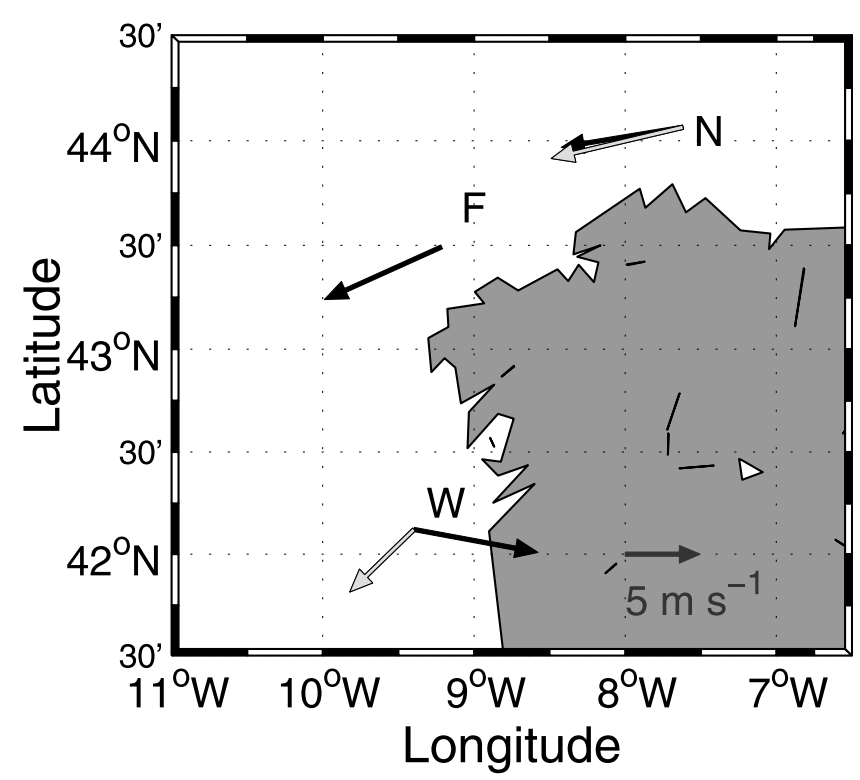

Figure 14. Example of measured winds from the offshore buoys on 7 July 1999 (black) and 20 March 2000 (light gray).

et al., 1994], producing nonlinear effects accompanying the acceleration of the flow around the capes, and a cyclonic tendency downstream. Doming could help explain the persistence of the Finisterre filament following cessation of favorable wind patterns, but again, observational evidence of the detailed hydrographic and current structure near the cape is lacking.

[46] Winter winds in general showed larger variability than summer winds during both a "typical" (2000-2001) and "atypical" (1999-2000) seasonal year. Downwelling wind patterns emerged from CEOF analysis during both the 1999-2000 and winter 2001 analyses. E,NE and N winds were predominant during both winters reaching speeds in the range $15-20 \mathrm{~ms}^{-1}$, higher than the $10-15 \mathrm{~ms}^{-1}$ range of summer winds. However, their persistence was far less (4-6 days) than during summer ( $\sim 12$ days). Both winters saw the PUNC wind field predominate during sustained periods in March and February respectively. Its effect on the SST field was the disappearance on the north coast, but not the west coast, of the warm temperature anomaly indicative of poleward flow only.

[47] It is difficult to define transitional regimes, nonupwelling to upwelling and vice versa in terms of the wind forcing because of the absence of any clear seasonal cycle. Extension of the analyses to a longer period will provide better information, but it appears that as long as the meridional sea surface temperature gradient is present, (nearly until July) upwelling winds do not fully set up upwelling; even sustained winds provoking upwelling early in the season do not develop filaments, for example, April-May 2001.

\section{Conclusions}

[48] Our study of the QuikSCAT and in situ wind fields in the Galician upwelling region around Cape Finisterre has shown the following.
[49] 1. The wind field is far from homogeneous in the region so that wind observations at a single point, coastal or offshore, will not necessarily be representative of coastal conditions over any significant distance.

[50] 2. The wind field's long-term mean summer and winter patterns are not necessarily representative of particular years when, as we have seen, summer-like upwelling patterns may dominate in winter also.

[51] 3. Summer and winter time wind fields have a small number of dominant patterns, discernible in complex empirical orthogonal analysis, that are responsible for the typical distributions of upwelling and downwelling off the Galician coast.

[52] 4. One pattern produces north coast, but no west coast, upwelling. In summers when this pattern dominates, the Cape Finisterre filament is strong but no others develop. The filament is partly supplied by cold water from the north coast but also, importantly, by local open ocean upwelling produced by the wind stress curl, which extends in a maximum SW from the cape.

[53] 5. Another summer pattern produces west coast upwelling, but no north coast upwelling. When this pattern persists, west coast filaments develop at favored locations other than Finisterre and may extend up to $200 \mathrm{~km}$ offshore.

[54] 6. These patterns may alternate producing brief episodes of north or west coast upwelling with little filament development, or a combined pattern may occur that produces weak upwelling on both coasts with a localized maximum at Finisterre, where the wind lies parallel to the coast.

[55] 7. The onset of the winter poleward flow regime as indicated by presence of the warm water anomaly along the continental slope is delayed after the cessation of summer upwelling winds. Likewise the spring onset of upwelling lags significantly the commencement of favorable winds, though subsequent upwelling events respond rapidly to wind changes.

[56] Although there have been various significant efforts to observe facets of the Galician or Iberian upwelling over the years, for example, recently MORENA, OMEX II, there has never been a systematic effort to monitor its year-round physical development with simultaneous hydrographic, current and meteorological observations on the scale of the many California Current programs. The gradualist approach, while it has illuminated many aspects of the system, has left many basic questions like the 3-d structure, the spin up and spin down of upwelling, and the importance of alongshore propagating upwelling signals unanswered.

[57] Acknowledgments. The authors wish to thank Dr. A. Trasviña and Dr. G. Gutierrez of CICESE La Paz, Mexico for useful discussions and for providing facilities for writing up this work. This work was supported by the European Union under MAST 3 programme, contract number MAS3-CT97-0076 OMEX. Dr. E.D. Barton was partially funded by Mexican CONACYT, Catedra Patrimonial EX-010009.

\section{References}

Bakun, A., and C. S. Nelson, The seasonal cycle of wind stress curl in subtropical eastern boundary current regions, J. Phys. Oceanogr., 21, 1815-1834, 1991.

Barth, J. A., and K. H. Brink, Shipboard acoustic Doppler velocity observations near Point Conception: Spring 1983, J. Geophys. Res., 92, $3925-$ 3943, 1987.

Barton, E. D., M. E. Inall, T. J. Sherwin, and R. Torres, Vertical structure, turbulent mixing and fluxes during lagrangian observations of an upwel- 
ling filament system off northwest Iberia, Prog. Oceanogr., 51, 249-268, 2001.

Blanton, J. O., L. P. Atkinson, F. Castillejo, and A. L. Montero, Coastal upwelling of the Rías Bajas, Galicia, northwest Spain, I; hydrographic studies, Rapp.P.V. Reun. Cons. Int. Explor. Mer., 183, 179-190, 1984.

Castro, C. G., F. F. Pérez, X. A. Alvarez-Salgado, G. Rosón, and A. F. Ríos, Hydrography conditions associated with the relaxation of a upwelling event off the Galician coast (NW Spain), J. Geophys. Res., 99, 51355147, 1994.

Crepon, M., C. Richez, and M. Chartier, Effects of coastline geometry on upwellings, J. Phys. Oceanogr., 14, 1365-1382, 1984.

Dale, A. C., and J. A. Barth, The hydraulics of an evolving upwelling jet flowing around a cape, J. Phys. Oceanogr., 31, 226-243, 2001.

Davies, R. E., Predictability of sea surface temperature and sea level pressure anomalies over the North Pacific Ocean, J. Phys. Oceanogr., 6, 249-266, 1976.

Enriquez, A. G., and C. A. Friehe, Effects of wind stress and wind stress curl variability on coastal upwelling, J. Phys. Oceanogr., 25, 1651-1671, 1995.

Fiúza, A. F. G., M. E. de Macedo, and M. R. Guerreiro, Climatological space and time variation of the Portuguese coastal upwelling, Oceanol. Acta, 5, 31-40, 1982.

Frouin, R., A. Fiúza, I. Ambar, and T. J. Boyd, Observations of a poleward surface current off the coasts of Portugal and Spain during the winter, J. Geophys. Res., 95, 679-691, 1990.

Godin, G., The analysis of tides and currents, in Tidal Hydrodynamics, edited by B. B. Parker, pp. 675-709, John Wiley, New York, 1991.

Haynes, R., and E. D. Barton, A poleward flow along the Atlantic coast of the Iberian Peninsula, J. Geophys. Res., 95, 11,425-11,141, 1990.

Haynes, R., E. D. Barton, and I. Pilling, Development, persistence and variability of upwelling filaments off the Atlantic coast of the Iberian peninsula, J. Geophys. Res., 98, 22,681-22,692, 1993.

Huthnance, J. M., Circulation, exchange and water masses at the ocean margin: The role of physical processes at the shelf edge, Prog. Oceanogr., $35,353-431,1995$.

Huthnance, J. M., H. M. Van Aken, M. White, E. D. Barton, B. LeCann, E. F. Coelho, E. A. Fanjul, P. Miller, and J. Vitorino, Ocean margin exchange-water flux estimates, J. Mar. Syst., 32, 107-137, 2002.

Kelly, K. A., Comment on "Empirical orthogonal function analysis of advanced very high resolution radiometer surface temperature patterns in Santa Barbara channel" by G. S. E. Lagerloef and R. L. Bernstein, J. Geophys. Res., 93, 15,753-15,754, 1988.

Kosro, P. M., et al., The structure of the transition zone between coastal waters and the open ocean off northern California, winter and spring 1987, J. Geophys. Res., 96, 14,707-14,730, 1991

Kundu, P. K., and J. S. Allen, Some three-dimensional characteristics of low-frequency current fluctuations near the Oregon coast, J. Phys. Oceanogr., 6, 181-199, 1976.
McClain, C. R., S. Chao, L. P. Atkinson, J. O. Blanton, and F. de Castillejo, Wind-driven upwelling in the vicinity of Cape finisterre, Spain, J. Geophys. Res., 91, 8470-8486, 1986.

Merrifield, M. A., and C. D. Winant, Shelf circulation in the Gulf of California: A description of the variability, J. Geophys. Res., 94, $18,133-18,160,1989$

Miller, P. I., S. B. Groom, A. McManus, J. Selley, and N. Mironnet, Panorama: A semi-automated AVHRR, and CZCS system for observation of coastal and ocean processes, paper presented at 23rd Annual Conference and Exhibition of the Remote Sensing Society, Reading, UK, 1997.

Münchow, A., Wind stress curl forcing of the coastal ocean near Point Conception, California, J. Phys. Oceanogr., 30, 1265-1280, 2000.

Narimousa, S., and T. Maxworthy, Application of a laboratory model to the interpretation of satellite and field observations of coastal upwelling, Dyn. Atmos. Oceans., 13, 1-46, 1989.

Nogueira, E., Análisis y modelado de la variabilidad temporal de las caracteRísticas hidrográficas en la Ría de vigo, Ph.D. thesis, Univ. of Vigo, Vigo, Spain, 1998.

Nogueira, E., X. A. Alvárez-Salgado, F. F. Pérez, and G. Casas, Geostrophic wind-stress patterns in the NW Iberian upwelling system: A time series approach, paper presented at 3rd EU Conference: Exchange Processes at the Continent/Ocean Margins in the North Atlantic, Eur. Union, Vigo, Spain, 1997.

North, G. R., T. L. Bell, R. F. Cahalan, and F. J. Moeng, Sampling errors in the estimation of empirical orthogonal functions, Mon. Weather Rev., 110, 699-706, 1982.

Roed, L. P., and X. B. Shi, A numerical study of the dynamics and energetics of cool filaments, jets, and eddies off the Iberian peninsula, J. Geophys. Res., 104, 29,817-29,841, 1999.

Rosenfeld, L. K., F. B. Schwing, N. Garfield, and D. E. Tracy, Bifurcated flow from an upwelling center: A cold water source for Monterey Bay, Cont. Shelf Res., 14, 931-964, 1994.

Smyth, T., P. Miller, S. B. Groom, and S. J. Lavender, Remote sensing of physics and biology of Lagrangian experiments at the Iberian margin, Prog. Oceanogr., 51, 281-296, 2001.

Winant, C. D., C. E. Dorman, C. A. Frehe, and R. C. Beardsley, The marine layer off northern California: An example of supercritical channel flow, J. Atmos. Sci., 45, 3588-3605, 1988.

Wooster, W. S., A. Bakun, and D. R. Mclain, The seasonal upwelling cycle along the eastern boundary of the North Atlantic, J. Mar. Res., 34, $131-$ $141,1976$.

E. D. Barton, School of Ocean Sciences, University of Wales, Bangor, LL59 5AB, UK. (e.d.barton@bangor.ac.uk)

E. Fanjul, Puertos del Estado, Avda. del Partenón 10, 28042, Madrid, Spain. (enrique@puertos.es)

P. Miller and R. Torres, Plymouth Marine Laboratory, Prospect Place, West Hoe, Plymouth, L1 3DH, UK. (pim@pml.ac.uk; r.torres@pml.ac.uk) 